\title{
CLINICAL SPECIFICITY OF ADAPTATION DISORDERS IN STUDENTS
}

\author{
Maksim Khaustov \\ Department of Psychiatry, Narcology and Medical Psychology \\ Kharkiv National Medical University \\ 4 Nauky ave., Kharkiv, Ukraine, 61022 \\ haustov217@gmail.com
}

\begin{abstract}
Aim: To study the clinical features of the adaptation disorders state of medical students.

Material and methods of research: To solve the aim, following the principles of bioethics and deontology, a comprehensive clinical-anamnestic, clinical-psychopathological and psychodiagnostic examination of 412 students of both sexes (216 women and 196 men), Kharkiv National Medical University, average age 18.0 2.0 years. Among the surveyed 215 students of eastern Ukraine; 87 students - residents of Luhansk and Donetsk regions, enrolled in KhNMU to the beginning of the ATO and 110 students - migrants from the ATO zone.

Research methods: clinical, psychopathological, psychodiagnostic, statistical.

Results As shown by the results of the study, $27.0 \pm 1.7 \%$ of students from eastern Ukraine, $36.4 \pm 1.9 \%$ of students from residents of Luhansk and Donetsk regions who entered KhNMU for the beginning of the ATO and $92.2 \pm 3.1 \%$ of students are migrants disadaptive states detected from the ATO zone.

In the course of the work, it was established that disadaptive states of medical students manifest anxiety and depressive disorders. Depressive disorders were characterized by a lowered background of mood, affect of anguish and expectation of unhappiness, psychomotor inhibition, fixation on negative events, depressive self-assessment, reduction of the level of impulses, the presence of moderate and severe depressive episodes on the Hamilton depression scale

Anxiety disorders were characterized by the dominance of the general anxious mood background with a sense of internal tension, anxiety with inability to relax, irritability, aptitude for affinity reactions, hyperesthesia, internal stress, violation of the sleep-wake cycle, presence of moderate and severe anxiety episodes on the Hamilton depression scale, high level of reactive anxiety and personal anxiety on the Spielberger-Khanin scale and excessive nervous and mental voltage on the Nemchin scale.

Conclusions.

Migrant students show a higher level of adaptation disorders, compared to students who enrolled in KhNMU at the beginning of the ATO, in $27.0 \pm 1.7 \%$ of the examined I groups, $36.4 \pm 1.9 \%$ of the examined II and $92.2 \pm 3.1 \%$ III group revealed disadaptive states.

The clinical picture of disadaptive states of presentation is a combination of anxiety and depressive symptoms with a predominance of moderate and severe anxiety and depressive episodes, high levels of reactive anxiety and personal anxiety and excessive psychological stress.
\end{abstract}

Keywords: medical students, disadaptation states, anxiety, depression, psychological stress, asthenia.

DOI: $10.21303 / 2504-5679.2019 .00850$

(C) Maksim Khaustov

\section{Introduction}

The modern period of development of Ukraine is characterized by a significant number of socially determined stress factors, resulting in a tendency to negative changes in the health of the population, among which one of the most significant is the increase in the number of disadaptive states and reactions [1].

In modern conditions, the main psychological and medical problem is the state of students' disadaptation, which violate the course of professional training. The prevalence of disadaptive disorders in the student population, according to the literature ranges from $5.8 \%$ to $61.35 \%$. They cause a decrease in performance, deterioration of academic adaptation and academic performance, as well as the quality of life of students $[2,3]$.

The main task of medical psychology in this case is ensuring high efficiency of professional activity and to prevent the emergence of disadaptive reactions and states, especially students, since the student age is a special period in personality development as a "crisis richness" (exam stresses, age problems, awareness of the content of professional activity as self-realization and self-actu- 
alization, etc.), and the saturation of the possibilities of the maximum development of the way the strengths and potential of the individual [4].

The active integration of Ukrainian society into the European Union determined the need for deep reforming of the education system in general, and in particular, in the field of medical personnel training, the mode has changed significantly and the intensity of the educational process has increased, as well as the workload has increased [5].

Being a multi-level dynamic process, adaptation is associated with changes in the activities of various organs and body systems and determines the level of human psychophysiological and mental health and the degree of overall performance at the biological, mental and socio-psychological levels [6].

Students of higher educational institutions draw special attention to themselves, since educational activities are characterized by a variety of overloads and high demands on the personality [7].

The student period, which is characterized by maximum imbalances in the levels and rates of physical and mental development, expressed by social contradictions, is one of the most favorable for the manifestation and development of disadaptation states [8].

Despite a fairly large number of studies of educational clinical and psychopathological features of these phenomena, as well as their relationship and ways of development, including in relation to a specific social and professional group of medical students [9].

Given the specificity of this stratum of society, differentiated psycho-correctional and psycho-prophylactic measures should be created to work with this contingent, taking into account the peculiarities of clinical manifestations and the formation of disadaptation states in students [10].

The above led to the relevance and need for this research.

\section{The aim of research}

To study the clinical features of the state of disadaptation of medical students.

\section{Materials and methods}

To achieve this aim, a comprehensive clinical, psychopathological and psychodiagnostic examination of 412 students of I-III courses of the Kharkiv National Medical University, both sexes (216 women and 196 men) aged 18.0 \pm 2.0 years was carried out in compliance with the principles of bioethics and deontology.

All surveyed were divided into three groups: 1 group - 215 - students, residents of Kharkiv, Poltava and Odesa regions; 2 group - 87 students, residents of Luhansk and Donetsk regions, enrolled in KhNMU for the beginning of the ATO; 3 group - 110 immigrant students from the ATO area.

The following survey methods were used in the work: clinical-psychopathological, psychodiagnostic using the questionnaire of severity of psychopathological symptoms of Derogatis (Symptom Check List-90-Revised - SCL-90-R), (according to N.Tarabrina, 2001), Hamilton's clinical scales of anxiety and depression (M. Hamilton, 1967), adapted to the ICD-10 (G. Panteleeva, 1988), Spielberger scales of situational and personal anxiety (in the adaptation of Yu. Khanin, 1981), neuropsychiatric stress questionnaire (T. Nemchin, 1984), correction test, abbreviated multivariate personality questionnaire (AMPQ) (L. Sobchyk, 1998).

Mathematical-statistical processing of the research results was carried out using specialized software packages (Statistica 6.0, MS Excel) using the Student's t-test method.

\section{Research results}

As shown by the research results, migrant students show a higher level of adaptation disorders, compared with students of groups I and II. It is established that $27.0 \pm 1.7 \%$ (58 people) of examined I groups, $36.4 \pm 1.9 \%$ (32 people) of examined II and $92.2 \pm 3.1 \%$ (101 people) of the examined III group have disadaptive states (Table 1).

For the clinical picture of adaptation disorders in the examined patients, inherent were complaints of low mood background (157 people, $82.5 \pm 2.5 \%$ of the examined), depressed mood (138 people, $72.2 \pm 2.1 \%$ ), anxiety, constant internal stress with inability to relax (159 people, $83.6 \pm 2.6 \%$ ), affect of anguish (76 people, $39.5 \pm 1.2 \%$ ), unwillingness to communicate (81 people, $42.3 \pm 3.4 \%$ ), 
hyperesthesia (76 people, $39.5 \pm 1.2 \%$ ), paresthesia (63 people, $33.1 \pm 1.0 \%$ ), loss of interest in surrounding events ( 75 people, $39.4 \pm 1.5 \%$ ), difficulties in learning the material (105 man, $55.2 \pm 1.8 \%$ ), violations of the sleep-wakeful cycle (difficulty falling asleep, disturbing the duration of sleep and its depth) (98 people, $51.2 \pm 1.7 \%$ ).

Table 1

Disadaptation level of students (\%)

\begin{tabular}{cccc}
\hline Disadaptation level & I group & II group & III group \\
\hline high & $0.5 \pm 1.1$ & $2.2 \pm 1.4$ & $25.4 \pm 1.6$ \\
expressed & $2.4 \pm 1.4$ & $9.2 \pm 1.4$ & $36.4 \pm 1.0$ \\
moderate & $24.1 \pm 1.7$ & $25.0 \pm 1.6$ & $30.4 \pm 1.1$ \\
Low or no & $73.0 \pm 2.1$ & $63.6 \pm 2.2$ & $7.8 \pm 1.3$
\end{tabular}

It is necessary to point that anxious experiences were associated with difficulties in adapting to educational activities at a medical university, lack of mutual understanding with peers, lack of confidence in the correctness of the chosen path and future prospects.

In all examined people, asthenic symptoms appeared - general weakness, malaise, fatigue, difficulty concentrating, low productivity of mental and physical labor.

Concentration was noted on the state of somatic ills, which was promoted by vegetative paroxysms, most often of the cardiovascular type (heavy feeling of pressure, chest contraction, a feeling of internal tremor) $(33.1 \pm 1.0 \%)$ and somato-allergic disorders in the form of cephalgia and cardialgia $-45.2 \pm 1.5 \%$ of the examined.

An analysis of the features of attention with the help of a correction test showed that students with adaptation disorders show reduced concentration, increased fatigue, decreased tolerance to stress (an average of 158.3 characters), a pronounced fatigue reaction - the maximum concentration of attention was observed in the examined 2 minutes (278.6 characters), with a decrease to 161.5 characters on average for 7 minutes. When performing a correction test in the first minute of the research, a high number of mistakes were identified, which gradually decreased in the second minute - "work in" occurred.

The SCL-90-R scale showed that a high level of somatization (1.64 \pm 1.4 points), depression (1.22 \pm 1.1 points), anxiety (1.07 \pm 1.5 points).

In the examined with adaptation disorders, the prevalence of moderate anxiety ( 73 people, $38.3 \pm 1.8 \%$ surveyed) and depressive (71 people, $37.2 \pm 1.7 \%$ ) episodes and severe anxiety (94 people, $49.3 \pm 2.1 \%$ ) and depressive (91 people, $47.6 \pm 1.9 \%$ ) episodes are noted (Table 2).

Table 2

The severity of anxiety and depression among students (\%)

\begin{tabular}{|c|c|c|c|c|}
\hline \multicolumn{2}{|c|}{ Severity of anxiety and depression } & \multirow{2}{*}{$\frac{\text { I group }}{4.2 \pm 1.4}$} & \multirow{2}{*}{$\begin{array}{c}\text { II group } \\
6.6 \pm 1.3\end{array}$} & \multirow{2}{*}{$\begin{array}{c}\text { III group } \\
46.1 \pm 1.0\end{array}$} \\
\hline Clinical & anxiety & & & \\
\hline manifestations & depression & $2.4 \pm 1.1$ & $18.2 \pm 1.4$ & $32.4 \pm 1.1$ \\
\hline \multirow{2}{*}{$\begin{array}{c}\text { Subclinical } \\
\text { manifestations }\end{array}$} & anxiety & $2.4 \pm 1.1$ & $18.2 \pm 1.4$ & $40.2 \pm 1.0$ \\
\hline & depression & $4.9 \pm 1.4$ & $15.6 \pm 1.4$ & $33.1 \pm 1.1$ \\
\hline \multirow{2}{*}{ Norm } & anxiety & $93.4 \pm 3.1$ & $75.2 \pm 2.3$ & $13.7 \pm 1.4$ \\
\hline & depression & $92.7 \pm 3.1$ & $66.2 \pm 2.2$ & $34.5 \pm 1.2$ \\
\hline
\end{tabular}


In $35.6 \pm 1.6 \%$ of the examined ( 68 people) with adaptation disorders were anxiety disorders moderate and in $51.1 \pm 2.2 \%$ (97 people) of high severity on the Spielberger - Khanin scale.

On a scale of neuropsychic tension, $33.5 \pm 1.7 \%$ of the examined (64 people) showed moderate ( $71 \pm 10$ points), $66.5 \pm 2.2 \%$ ( 68 people) excessive ( $80 \pm 10$ points) nervously mental stress.

As the research results of the study show, vegetative-vascular paroxysms were obligatory for the clinical picture of disadaptive states in students. In $35.6 \pm 1.7 \%$ of the examined vegetative crises began with chills, were accompanied by an accelerated heartbeat, often with a feeling of numbness or coldness of the extremities, that is, they had a sympatho-adrenaline orientation; in $33.2 \pm 1.6 \%$ of the weight-insulatory orientation, started from the elements of "heart sinking", shortness of breath, feelings of "heat influx to the face or body", which changes with chills and tachycardia; in $29.8 \pm 1.2 \%$ of the examined structure, the crisis could be classified as mixed, which was closely intertwined with both sympatho-adrenaline and weight insular manifestations.

A study of the individual psychological characteristics of the students' personality showed differences in the personality profile of students according to the AMPQ scales, depending on the presence of disadaptation states (Table 3).

Table 3

Personality characteristics of students according to the AMPQ method (points)

\begin{tabular}{ccccc}
\hline \multirow{2}{*}{ Scales } & \multicolumn{2}{c}{ Without disadaptation } & With manifestations of disadaptation \\
\cline { 2 - 5 } & M & W & M & W \\
\hline L & 51.58 & 50.02 & 53.54 & 46.93 \\
F & 45.625 & 49.01 & 50.62 & 56.25 \\
K & 54.48 & 54.95 & 54.48 & 51.06 \\
Hs & 59.59 & 54.55 & 59.58 & 58.37 \\
D & 44.82 & 51.52 & 50.93 \\
Hy & 42.66 & 41.94 & 55.5 & 46.49 \\
Pd & 38.69 & 39.71 & 49.36 & 49.15 \\
Pa & 38.85 & 40.84 & 43.2 & 42.44 \\
Pt & 39.99 & 37.65 & 48.7 & 45.96 \\
Sc & 40.0 & 40.83 & 50.01 & 47.27 \\
Ma & 41.81 & 43.78 & 47.5 & 50.7
\end{tabular}

As the research results show, men have higher rates of hypochondria and depression than women. The highest values among students without signs of mental disadaptation are achieved by indicators of the hypochondria scale. It should be noted that scales of lies, correction and reliability are rather close to the average norm.

Comparing the AMPQ profile in adapted and disadapted students in general, it is possible to say that for women with disadaptation signs, characteristic deviations of the scales of depression, hypochondria, hysteria, psychopathy, and psychasthenia, while in the adaptation of female students, the greatest deviations are observed in the scales of hypomania and hypochondria. In men with impaired adaptation, deviations of hypochondria, depression, hypomania, and schizophrenia scales are most often observed. It should be noted that fluctuations in the value of the scales occur within the average norm (40-60), however, indicators of psychopathy, paranoia and psychasthenia go beyond these limits.

Based on the obtained data, reflecting the mechanisms of formation of adaptation disorders in students, we have developed methods for their correction. 


\section{Discussion of research results}

Anxiety disorders are characterized by dominance of general anxiety mood with a feeling of internal tension, anxiety with inability to relax, irritability, aptitude for affective reactions, hyperesthesia, internal tension, disturbance of sleep-wakeful cycle, the presence of moderate and severe anxiety episodes on the Hamilton depression scale, high the level of reactive anxiety and personal anxiety on the Spielberger - Khanin scale and excessive psychological stress on the Nemchin scale.

The obtained data on psychological manifestations of students' adaptation disorders correlate with the data of Ukrainian researchers [11, 12], however, an analysis of the structure of emotional disorders in the structure of the clinical picture of disadaptive states of medical students is new.

\section{Conclusions}

1. Immigrant students exhibit a higher level of adaptation disorders, compared with students of groups I and II, in $27 \pm 1.7 \%$ of the examined groups I, $36.4 \pm 1.9 \%$ of the examined II and $92.2 \pm 3.1 \%$ of the III group revealed disadaptive states

2. The clinical picture of disadaptive states is represented by a combination of anxiety and depressive symptoms with a predominance of moderate and severe anxiety and depressive episodes, high levels of reactive anxiety and personal anxiety and excessive psychological stress.

\section{References}

[1] Malakhov, P. S., Asieieva, Yu. O., Kharitonova, A. S. (2016). Problemnist adaptatsii studentiv-medykiv. Medychna psykholohiia, 2, 3-5.

[2] Korniienko, O. V. (2015). Indyvidualno-typolohichnyi (introvertovanyi) ta faktornyi analizy psykhosomatychnoho zdorovia studentok-divchat Kyivskoho natsionalnoho universtytetu imeni Tarasa Shevchenka. Humanitarnyi visnyk DVNZ «Pereiaslav-Khmelnytskyi derzhavnyi pedahohichnyi universytet imeni Hryhoriia Skovorody», 35, 144-151.

[3] Chaban, O. S., Khaustova, O. O., Trachuk, L. Ye. (2016). Shliakhy pidvyshchennia efektyvnosti navchannia studentiv za spetsialnistiu «Medychna psykholohiia». Medychna psykholohiia, 11 (1), 3-8.

[4] Kovalenko, M. V. (2014). Strukturnyi analiz perfektsionizmu ustudentiv vyshchykh navchalnykh medychnykh zakladiv. Ukrainskyi visnyk psykhonevrolohii, 22 (3 (80)), 65-68.

[5] Aimedov, K. V., Strelbytska, S. M. (2014). Profesiina mobilnist maibutnikh fakhivtsiv u protsesi navchannia u VNZ: kompetentnisnyi pidkhid. Naukovo-metodychnyi zhurnal «Naukovi pratsi». Seriia: pedahohika, 251 (239), 49-52.

[6] Pshuk, N. H., Slobodianiuk, D. P. (2015). Rol psykhosotsialnykh chynnykiv v genezi sotsialnoi dezadaptatsii u studentskoi molodi. Ukrainskyi visnyk psykhonevrolohii, 23 (2 (83)), 86-91.

[7] Iureva, L. N. (2017). Krizisi professyonalnoi deiatelnosty vracha i puti ikh preodolenyia. Zdorovia Ukrainy, 2 (41), 23-24.

[8] Herasymenko, L. O. (2018). Psykhosotsialna dezadaptatsiia (suchasni kontseptualni modeli). Ukrainskyi visnyk psykhonevrolohii, 26 (1 (94)), 62-65.

[9] V`iun, V. V. (2017). Pryntsypy ta alhorytmy psykhoterapevtychnoi korektsii rozladiv adaptatsii u likariv interniv. Ukrainskyi visnyk psykhonevrolohii, 25 (3 (92)), 26-28.

[10] Leshchyna, I. V. (2011). Skryninhova diahnostyka nepsykhotychnykh psykhichnykh rozladiv u studentiv-medykiv. Visnyk problem biolohii i medytsyny, 1 (2), 131-135.

[11] Kiosieva, O. V. (2016). Psykhopatolohycheskaia kharakterystyka emotsyonalnoi sferi u studentov mladshykh kursov. Ukrainskyi visnyk psykhonevrolohii, 24 (1 (86)), 60-63.

[12] Kozhyna, H. M., Markova, M. V., Grinevich, E. G., Zelens'ka, K. O. (2011). K probleme adaptatsyonnoho syndroma studentov mladshykh kursov VUZov III-IV urovnei akkredytatsyy. Arkhiv psykhitrii, 17 (4 (67)), 32-35. 